\section{EL PAISAJE Y EL ENFOQUE DE HÁBITAT RESIDENCIAL}

Mario Torres Jofré

\section{THE LANDSCAPE AND THE RESIDENTIAL HABITAT APPROACH}

\author{
Mario Torres Jofré
}

More than seven years ago, the Housing Institute of the Faculty of Housing and Urban Planning at the University of Chile conceived, prepared and developed the Master's program in Residential Habitat. Unlike other programs, this course of study is not a response to a disciplinary derivative as it aims to highlight the need to face the quality of life challenge and the sustainability of human settlements from a multidisciplinary and, for some people, transdisciplinary perspective. In this sense, the Housing Institute understands the concept of residential habitat as:

... the result of a process that constantly creates places at different territorial scales, the latter being 
particular de apropiación, dado por un vínculo cotidiano con unidades de experiencias singulares, potenciando relaciones de identidad y pertenencia, a partir de lo cual el habitante lo interviene y configura...

Es así como las dimensiones explicativas del enfoque: socio-cultural, política-económica y físicoespacial, debían reflejarse en la malla curricular no a través de los tradicionales nombres de las disciplinas, sino por nombres que fuesen lo suficientemente amplios, a fin de permitir que el enfoque de hábitat residencial se mantuviese permanentemente en tensión y búsqueda. No fue posible conseguirlo en todos los casos, pero las asignaturas que son parte constitutiva de su ser permiten evidenciar la importancia multidisciplinar para enfrentar la investigación científica y la investigación aplicada, con el objetivo de mejorar la calidad de vida y la sostenibilidad de los asentamientos humanos.

En la línea de lo señalado, la dimensión físico-espacial quedó reflejada en una de tres asignaturas, con la denominación "Paisaje natural y construido". Se buscaba con ello presentar esta dimensión del hábitat residencial bajo una concepción similar a la definición de paisaje que entregaba la Convención Europea del Paisaje (2000): se entenderá cualquier parte del territorio tal como lo percibe la población, cuyo carácter sea el resultado de la acción y la interacción de factores naturales y/o humanos. De este modo, la relación con las otras dos dimensiones, distinguished by particular appropriation methods defined by a daily link with unique experiences that encourage relationships of identity and belonging to intervene and configure landscapes...

Instead of using the generic designation of each discipline and in order to ensure a permanent tension and investigative spirit regarding residential habitat, the names of the different explanatory dimensions (socio-cultural, politicaleconomic and physical-spatial) included in our curriculum were planned to reflect wider concepts. While such an objective was partly achieved, the key subjects of this program that were actually given the intended name demonstrated the importance of multidisciplinarity. The idea was to face scientific research and applied investigation with an eye to improving the quality of life and sustainability of human settlements.

In this sense, the physical-spatial dimension was reflected in one out of three subjects under the name of "Constructed and Natural Landscape». This course was designed as an introduction to such a residential habitat dimension by using the same notion of landscape described by the European Landscape Convention (2000) as: any portion of the territory as perceived by people, whose character is the result of the action and interaction of natural and/or human factors. In this way, the relationship between the socio-cultural and political-economic dimensions 
socio-cultural y política-económica, quedaba resguardada y se hacía multidisciplinar.

Más aún, la percepción de un sujeto o de un conjunto de habitantes de una realidad determinada (si es que existe tal realidad), es producto de las características biológicas personales, de las construcciones culturales, de las relaciones sociales y económicas, de las que ofrece el espacio físico o geográfico, entre otras. Todas ellas, procesadas por un conjunto de filtros sensoriales e instintivos, posibilitan tanto las valoraciones positivas como negativas del hábitat en el cual se encuentran. Estas percepciones, que posibilitan valoraciones positivas o negativas, se asocian a un descriptor principal: el placer o el desplacer.

Para la RAE, la palabra placer y desplacer tienen varias acepciones:

placer. (Del lat. placēre). 1. intr. Agradar o dar gusto... placer. 1. m. Goce, disfrute espiritual. 2. m. Satisfacción, sensación agradable producida por la realización o suscepción de algo que gusta o complace. 3. m. Voluntad, consentimiento, beneplácito. 4. m. Diversión, entretenimiento... placer. (Del cat. placel, de plaza). 1. m. Banco de arena o piedra en el fondo del mar, llano y de bastante extensión. 2. $\mathrm{m}$. Arenal donde la corriente de las aguas depositó partículas de oro. 3. m. Pesquería de perlas en las costas de América. 4. m. Cuba. Campo yermo, o remained on hold and adopted a multidisciplinary approach.

Furthermore, the perception of an individual or a group of residents have of reality (if it actually exists) is the product of personal physiological characteristics, cultural constructions, social and economic relationships and the connection offered by physical or geographic spaces, among others. All these variables, when processed through different sensorial and instinctive filters, give room to positive or negative valuations regarding the habitat they are located in. Such perceptions are related to a primary descriptor: pleasure and displeasure.

There is a series of meanings for the words pleasure and displeasure:

pleasure.n 1. an agreeable or enjoyable sensation or emotion 2. something that gives or affords enjoyment or delight 3. amusement, recreation, or enjoyment 4. (euphemistic) sexual gratification or enjoyment 5. a person's preference or choice $v$ 6. when intr, often foll by in to give pleasure to or take pleasure (in) ${ }^{1}$.

displeasure. $\boldsymbol{n}$ 1. the condition of being displeased 2. (archaic) a. pain b. an act or cause of offence van archaic word for displease ${ }^{2}$.

Real Academia Española, 2001, p. 1776.

Ibíd, p.799. 
terreno plano y descubierto, en el interior o en las inmediaciones de una ciudad... ${ }^{1}$

desplacer. (De des- y placer). 1. m. Pena, desazón, disgusto... desplacer. (De des- y placer). 1. tr. Disgustar, desazonar, desagradar... ${ }^{2}$

De las acepciones a los dos lemas, es posible apreciar que mayoritariamente dicen relación con una percepción sensorial del sujeto respecto de hechos objetivos y concretos a los cuales les asigna un valor positivo o negativo.

Por tanto, la idea de paisaje contiene, simultáneamente, referencias a un hecho objetivo y a realidades intimamente ligadas a las características personales de un sujeto. Así, es factible señalar que la percepción es enseñada, aprendida y mitificada siguiendo distintas vías de comunicación o transmisión. Por medio de la percepción y las condiciones de placer, se da que en el enfoque de hábitat residencial, el paisaje natural y construidose encuentra con las otras dimensiones en las cuales los hombres y mujeres se desarrollan, el acento está puesto en el territorio como lugar donde se materializa la calidad de vida y la sostenibilidad.

Referir el paisaje natural y construido bajo el enfoque de hábitat residencial implica dejar de comprender una valoración restrictiva del término paisaje y preocuparse por todos aquellos aspectos
These two definitions refer mostly to the sensorial perception of an element in relation to objective and concrete facts that may be positively or negatively valued.

Therefore, the idea of landscape simultaneously refers to objective facts and realities closely related to the personal characteristics of an individual. Thus, it is possible to suggest that perception is taught, learnt and mythologized by different communication or transmission methods. Within a residential habitat context, natural and constructed landscapes meet the other dimensions in which men and women participate. The emphasis is then the territory, where quality of life and sustainability materialize.

Analyzing the natural and developed landscape from a residential habitat perspective entails getting rid of the restrictive value contained within the concept of landscape and focusing on those aspects that determine the quality of the environment of a large number of residents in urban and rural areas around the world. Since the natural and constructed landscape may relate to new restrictions of productive activities as part of the residential habitat it runs the risk of facing political and economic constraints. However, a proper land planning and management utilizing this approach may become

1 Real Academia Española, 2001, p. 1776.

2 Ibíd, p. 799. 
que condicionan la calidad del entorno de ingentes números de habitantes de zonas urbanas y rurales a nivel mundial. El paisaje natural y construido como instrumento del enfoque de hábitat residencial puede verse enfrentado a reticencias políticas y económicas, al asociarse con posibles nuevas restricciones de actividades productivas, como sucede en varios casos. Sin embargo, una adecuada ordenación y gestión del territorio bajo este enfoque, puede transformarse en uno de los mayores aportes frente a las políticas globales y particulares del desarrollo sostenible.

En este orden de ideas y siguiendo a Romani:

\begin{abstract}
El paisaje, cualquier cosa que sea, nos aparece como un conjunto extraordinario y complejo de muchos elementos relacionados entre sí, compuesto de árboles, de rocas y de campos, de aguas y de economías, de hombres, de culturas, de acciones, de causas y efectos, de relaciones, eventos y procesos históricos; pero al mismo tiempo nos damos cuenta que aquello no puede ser restituido en forma simple e imaginativa, porque su verdadera naturaleza y esencia real es como aquella de los tantos elementos que componen el universo, siendo aun más dinámica y envolvente. ${ }^{3}$
\end{abstract}

Los elementos asociados a paisaje natural y construido han condicionado las actividades humanas, que a su vez establecen la caracterización del territorio traduciéndose en la imagen o identidad de

3 Romani, 1994, p. 9. (Traducción del autor). assents when facing the global and particular policies of sustainable development.

\section{In connection to this, and according to Romani}

Whatever the landscape may be, it is a manifestation ofa complex and extraordinary series of interrelated elements, including trees, rocks, fields, water, economies, men, culture, actions, causes and effects, relationships, events and historical processes; however, we realize that these elements cannot be restored in a simple and imaginative manner since their nature and essence is like those of the elements of which the universe is made of, thus becoming even more dynamic and enveloping. ${ }^{3}$

Those elements associated to the natural and developed landscape have conditioned the human activities which, in turn, define the characterization of a territory that becomes the image or identity of a given place. Likewise, the group of objective or subjective elements comprising the natural and developed landscape form a unique and inseparable unit. In this sense, the constant evolution and the fact of manifesting themselves as a harmonious and balanced group are the factors that distinguish these elements from independently valued constituents.

The residential habitat approach can be found in the physical-spatial dimension of human-induced

3 Ibíd, 1994, p.9. 
cada lugar. El grupo de elementos que integran el paisaje natural y construido, ya sean considerados de carácter objetivo o subjetivo, forman un conjunto único, indisociable. En esto se diferencia de los propios elementos que pueden ser valorados independientemente en sí mismos, que evoluciona de manera constante y que en ocasiones puede manifestarse como un todo integrado en forma armónica y equilibrada.

El enfoque de hábitat residencial se presenta en la dimensión físico-espacial en un paisaje de características antrópicas, resultado de la interrelación entre personas y estructuras urbano-territoriales, capaces de construir hitos en la vida individual y comunitaria. Esta capacidad depende de la valoración que dichos individuos hagan sobre el espacio construido, por lo cual la calidad de este último resulta fundamental en cuanto a la conformación de factores de agrado y significación. También, es un paisaje considerado como recurso. Forma parte del patrimonio de los individuos y de las sociedades, en sus diferentes niveles escalares, pues se trata de una construcción social, o quizás, una imagen mental con reconocimiento colectivo. Por una parte, imagen de la realidad y, por otra parte, la realidad misma, dos ámbitos complementarios del paisaje natural y construido.

El paisaje natural y construido no es sólo la huella de crecimientos económicos y desarrollos, sino que es el marco visual de criterios administrativos landscapes and is the result of the interrelation between individuals and urban-territorial structures, the latter being able to create individual and communal landscapes. Such a feature depends on how people value this constructed space; in this sense, the quality of space is essential as far as the generation of pleasure and significance is concerned. This type of landscape is also regarded as a resource and, given its condition of social construction or a mental image that can be collectively recognized, forms part of the heritage of individuals and societies at different levels. On the one hand, it reflects the image of reality; on the other hand, it represents reality itself. These two complementary domains of the natural and constructed landscape addressed in this approach.

This natural and constructed landscape do not only reflect economic growth and development, it is also the visual framework of an administrative criteria having a bearing on territorial management and planning, with a focus on urban land. This translates into public policy, management and design criteria, in which each project has an effect on the creation or destruction of places that involves a physical change of perception regarding the image of reality or the reality itself.

There is no doubt that administrations are not ready to cope with the fast cultural, economic, social and 
que influyen en el cómo manejar y conformar el territorio, principalmente el urbano. Esto se traduce en criterios de política pública, gestión y diseños, donde cada proyecto influye en la creación o desaparición de lugares, donde directamente hay un cambio físico de percepción frente a la imagen de la realidad o a la realidad misma.

Sin duda, las administraciones no están preparadas para hacer frente a las rápidas transformaciones que se asocian al siglo XXI -culturales, económicas, sociales y tecnológicas-. Aquellas han superado en velocidad a la capacidad de aprendizaje en la gestión del paisaje natural y construido y sus elementos en las poblaciones locales, permitiendo la pérdida de la valorización de riquezas visuales y genéticas que conforman los espacios donde se desarrolla la vida.

Actualmente la vida pública y cotidiana de las personas está dominada por actividades que en muchos casos las administraciones no dimensionan. Actividades que acompañan al desarrollo social y cultural de cada lugar, pero que a través del tiempo han evolucionado de tal manera que fuerzan al espacio a presentarse dinámico y diligente frente a estos cambios. Muchas de estas propuestas de crear e incentivar espacios "activos", "seguros" y "sostenibles" se da por presiones, necesidades, intereses y actividades, que luego cambian el estilo de vida de las personas y sus propias demandas. technological transformations of the twenty-first century. As far as local populations are concerned, these changes have exceeded the learning ability in the management of natural and constructed landscapes and their respective elements, thus allowing the loss of visual and genetic valuation conforming the spaces where life evolves.

Today, the public and daily life of people is governed by activities that are not properly measured by local governments. These activities tend to go hand in hand with the social and cultural development of a given place; however, they have evolved to such a point that space is forced to act in a dynamic and diligent manner to suitably address them. A large number of these proposals aimed at creating and promoting «active», "safe»y "sustainable» spaces are the result of pressure, needs, interests and activities that modify the demands and lifestyle of people.

In many cases, people use these spaces just because they have to, regardless the quality of the natural and constructed landscape. However, it is at this point that the residential habitat approach redirects each of the aspects affecting the composition of places; in this reorientation, the quality and the sense of belonging are transformed into a key life and death factor in urban and rural areas. In this sense, landscape is analyzed from a building perspective that synthesizes 
Se entiende que en muchos casos las personas utilizan el espacio porque lo tienen que hacer, independiente de la calidad del paisaje natural y construido. Sin embargo, el enfoque de hábitat residencial da un vuelco en ello, por medio de una reorientación de cada uno de los aspectos que influye en la composición de los lugares, donde la calidad de los mismos y el sentido de pertenencia que se puedan crear con la comunidad, se transforman en un factor crucial de vida o muerte de zonas urbanas y rurales. Se intenta la comprensión del paisaje desde la óptica de la construcción de lugar, que sintetiza la mirada visual-artística y la del uso social que se da en el enfoque de hábitat residencial.

Mas, surge la interrogante frente a la relación diseño y gestión, ya sea esta pública o privada. El paisaje es opinión y materia de todos, y a medida que se va teniendo una comunidad informada, la participación comienza a tomar relevancia. La visión actual del paisaje natural y construido implica simultáneamente el diseño del espacio como una unidad estética y como una configuración medioambiental, es decir, la construcción de un lugar público.

La dinámica del ser humano conjuga características físicas, sociales y culturales, mismos aspectos que pueden ser reflejados en una integración entre el espacio y el ser humano, que se ve reflejada en el buen uso y la gran aceptación de un lugar, como también the visual-artistic approach and its social use at residential habitat level.

However, the question regarding the designmanagement relationship, both at public and private level, arises. Everyone can discuss landscapes and, as the community becomes more informed, the participation of people in this debate will increase. The current approach to the natural and constructed landscape implies the design of space as an aesthetic unit and as an environmental configuration; in other words, it refers to the construction of public space.

The dynamics of human beings brings together physical, social and cultural characteristics; these very features may be reflected in a space-human being relationship defined by either the proper use and acceptance or the disuse and rejection of a given place. In this way, the design of space ensures the construction of places which, according to the sensation of pleasure they produce on people, may turn into landscapes. Such a transition is possible because landscapes are social and cultural constructions, visual realities or mental images that recognize a series of basic principles within the configuration of a natural and constructed environment.

Landscape is an area that has been modified by humans. In fact, the semantic definition of this 
puede traducirse en no uso y rechazo de un lugar. Así, el diseño del espacio posibilita la construcción de lugar y de estos lugares, según la condición de agrado que generen en sus habitantes. Se constituyen en paisajes, que son una construcción social, una construcción cultural, una realidad visual, o una imagen mental de reconocimiento de un conjunto de principios básicos que configuran el medio ambiente natural y construido.

El paisaje es aquella superficie terrestre que ha sido objeto de transformaciones antrópicas (humanas), aunque la traducción anglosajona de "landscape" identifica también el paisaje como el jardín y, por ende, con la armonía artificial obtenida arquitectónicamente a partir de elementos y materiales naturales. El paisaje es entonces una totalidad dinámica y unitaria del mundo que se vive, puesto que el mundo, biótico y abiótico, natural y humanizado, es constituido por una serie de elementos que expresan la diversidad y la diferenciación. Estas dos últimas incorporan espontáneamente un nivel creciente de organización.

Si bien el No 78 de la Revista INVI estaba destinado a ser receptor de diversos artículos bajo una temática libre, no es menos cierto que éste ha quedado estructurado con una columna vertebral, que -de forma explícita o implícita- nos refiere al paisaje natural y construido.

En el primer artículo, que lleva por título "Lectura transdiciplinar de paisajes cotidianos, word refers to gardens, and thus to the artificial architectural harmony obtained from natural materials and elements. Landscape is, then, a dynamic and unitary whole of the world, since this biotic and antibiotic, natural and humanized planet is composed of a series of elements expressing diversity and differentiation. It is worth noting that these last two concepts show a considerable organizational level.

In spite of being intended to offer open subjects, the backbone of this issue of Revista INVI, explicitly or implicitly, refers to natural and constructed landscapes.

The first paper, «Transdisciplinary Analysis of Everyday Landscapes, towards a Heritage Valuation. Approximation Method", written by Juan Francisco Ojeda, is the result of a series of research studies on landscape in Sierra Morena, Andalusia, and offers a methodology for the analysis of any landscape reality. The author implicitly demonstrates that the original method to represent the physicalspatial approach to residential habitat was right:

"Given that landscapes bring together natural elements, historical events, and different perceptions, representations and symbolizations, this analysis makes a transition from multidisciplinarity to interdisciplinarity before concluding with a transdisciplinary approach" 
hacia una valoración patrimonial. Método de aproximación", Juan Francisco Ojeda ofrece una metodología para la lectura de cualquier realidad paisajística como resultados de investigaciones sobre paisaje en Sierra Morena, Andalucía. El autor, implícitamente, deja en evidencia que la búsqueda original para presentar la dimensión físico-espacial del enfoque de hábitat residencial no estaba errada, toda vez que indica:

...El ejercicio de lectura experta irá transitando de la multidisciplinariedad a la interdisciplinariedad, para terminar siendo transdisciplinar. Teniendo en cuenta que-como se ha dicho-en un paisaje convergen componentes naturales, hitos históricos y percepciones, representaciones y simbolizaciones...

...nuestra lectura hermenéutica de paisajes se basa en la acumulación de saberes previos, en la traducción de los mismos al lenguaje divulgativo, hasta llegar a construir un relato actual de ellos...

...Todo ello debe resultar especialmente aplicable en los campos de la docencia y de la planificación y ordenación normativa de los paisajes en el futuro...

A lo anterior se podría agregar su aplicación en la comprensión del hábitat residencial y la construcción de lugares con mejor calidad de vida y sostenibilidad.

Angélica Patricia Camargo Sierra y Adriana Hurtado Tarazona presentan el artículo titulado "Urbanización informal en Bogotá: agentes y lógicas de producción del espacio urbano". Sin duda la
"... this hermeneutical analysis of landscape is based on the accumulation of previous knowledge and its subsequent translation into informative language. The objective is to elaborate an account of landscapes..."

"This methodology is particularly applicable to the fields of teaching and the planning of guidelines for future landscape projects."

Such a methodology could be also used to understand residential habitat and the construction of places aimed at offering better quality of life and sustainability conditions.

The second paper is a piece prepared by Angélica Patricia Camargo Sierra and Adriana Hurtado Tarazona entitled «Informal Land Development in Bogotá: Agents and Production Philosophies of Urban Spacen. There is no doubt that the informal land development (a phenomenon that can be observed not only in Bogotá, but in many cities around the world) is a unique landscape generated by a particular form of construction of urban and periurban space. In this regard, while this article aims at:

«... solving three questions: how much (and where) has the informal land development grown over the last century in Bogotá? How do the informal land and housing factors (supply, demand, State intervention) act in relation to the informal land and 
urbanización informal, no sólo en la ciudad de Bogotá sino en muchas ciudades localizadas en los cinco continentes, representa un paisaje particular generado por una forma particular de construcción del espacio urbano o periurbano. Tal como lo señalan las autoras, el artículo trata de

...resolver tres preguntas: ¿Cuánto (y dónde) ha crecido la urbanización informal en Bogotá en el último siglo? ¿Cómo se comportan los agentes relacionados con el mercado informal de suelo y vivienda (oferta, demanda, intervención estatal)? ¿Qué tipo de espacio urbano ha producido y está produciendo la urbanización informal?

Los efectos de la urbanización informal en el crecimiento de la ciudad y la ocupación de tierras agrícolas; en el mercado informal y la política pública; y en el espacio construido, implican cambios en la morfología del territorio y en las relaciones económicas dentro de él. Sin embargo, además de las explicaciones cuantitativas que se ofrecen, implican un cambio en las características del territorio, un cambio en el paisaje natural y construido, que implícitamente queda de manifiesto con una lectura experta multidisciplinar del artículo.

Siguiendo en la línea anterior se publica el artículo "Ciudad y hábitat informal: Las tomas de terreno y la autoconstrucción en las quebradas de Valparaíso", de Andrea Pino Vásquez y Lautaro Ojeda Ledesma. Producto de una investigación de tesis doctoral, los autores privilegiarán los relatos de housing markets? and What kind of urban space has been and is being produced by the informal land development?»

The effects of this phenomenon on the city growth and the use of agricultural lands, as well as on informal markets, public policies and developed spaces imply changes in both the morphology of land and the economic relationships involved in it. However, apart from offering quantitative explanations, such as that an informal development modifies the characteristics of a territory. It is a change in the natural and developed landscape that is implicitly evidenced after a multidisciplinary expert analysis.

This issue of Revista INVI continues with «City and Informal Habitat: Illegal Occupation of Land and Self-help Construction in the Ravines of Valparaíso», co-authored by Andrea Pino Vásquez and Lautaro Ojeda Ledesma. As part of a doctoral thesis, the authors of this contribution emphasize the accounts of life over the richness of its content in order to corroborate the proposed hypothesis:

1- The informal habitat in the Valparaiso ravines is the result of the illegal occupation of land carried out by individuals or small families in search of family mobility.

2-Successive earthquakes triggered the occupation of ravines. 
vida por la riqueza de su contenido, con el propósito de corroborar las hipótesis de ella:

1- El hábitat informal en las quebradas nace de tomas de terreno de carácter individual y/o de pequeños grupos familiares, que obedecen a una lógica de movilidad familiar.

2- Los terremotos están en el origen de la ocupación de las quebradas.

Ambas hipótesis se constituyen como las principales causas de ocupación y a través del tiempo dieron origen a los conjuntos residenciales familiares (C.R.F) de las quebradas de Valparaíso.

Qué más natural que un terremoto y que la geomorfología resultante de miles de años de evolución para expresar cambios en el paisaje. Más aún cuando estos elementos dan origen a una forma de apropiación y ocupación del territorio. Son los mismos autores los que comprenderán el hábitat informal en las quebradas de Valparaíso, que no es otro que el hábitat residencial, como paisaje en tanto construcción social, que resulta de una proyección cultural sobre un espacio determinado y apropiado por necesidades y posibilidades, materializado en tres escalas: urbana, barrial y familiar.

En el cuarto lugar de este número de la Revista INVI se vuelve a la ciudad de Bogotá con Jaime Hernández García, quien ofrece el artículo "Construcción social de espacio público en barrios populares de Bogotá". Al igual que el anterior, da cuenta de parte de la investigación doctoral del
These hypotheses are the main causes of occupation which, over the course of time, generated the Family Residential Complexes (FRC) of Valparaíso ravines.

Earthquakes and the geomorphology resulting from thousands of years of evolution are more than logical reasons to explain the changes undergone by landscape, especially when these very elements are conducive to a particular form of land appropriation and occupation. The authors of this paper realize that the informal habitat found in the Valparaiso ravines is no other than residential habitat, the latter being a social construction resulting from a cultural projection over a given space appropriated by needs and possibilities and materialized at urban, neighborhood and family scale.

The fourth contribution offered in this issue, entitled «Social Construction of Public Space in Popular Neighborhoods of Bogotá» and written by Jaime Hernández García, accounts for part of the doctoral thesis conducted by this author. This paper does not explicitly refer to landscape, but it focuses on the construction of places; in this sense, it is worth pointing out that this contribution remains faithful to the aforementioned approach of explaining the concept of landscape from a residential habitat perspective. This is possible thanks to a reorientation of each of the aspects that have an effect on the composition of places, in which the quality these 
autor. Aquí no se refiere el paisaje en forma explícita, sino que se hace hincapié en la construcción de lugar y es posible señalar que se da en la línea expresada en párrafos precedentes al explicar el paisaje en el enfoque de hábitat residencial. Esto, por medio de una reorientación de cada uno de los aspectos que influyen en la composición de los lugares, donde la calidad de los mismos y el sentido de pertenencia que se puedan crear con y en la comunidad:

...se discute la construcción social de espacio público en
los barrios populares en términos de cómo los individuos
interactúan con él. En este sentido, el consumo del es-
pacio público se puede ver a través de las actividades
de los habitantes que lo transforman para satisfacer sus
propias necesidades. En los asentamientos populares,
estas actividades están dadas en primera instancia por
las prácticas sociales y culturales que se llevan a cabo en
los espacios públicos. Abarcan principalmente la socia-
lización, los acontecimientos de la comunidad, las ma-
nifestaciones tradicionales y las expresiones religiosas y
politicas.

Este número de Revista INVI nos entrega artículos procedentes de tres países: España, Colombia y Chile. El que procede de Chile se localiza en la ciudad de Santiago. Magdalena Vicuña del Ríoofrece "El marco regulatorio en el contexto de la gestión empresarialista y la mercantilización del desarrollo urbano del Gran Santiago, Chile". Aquí sale a la palestra la administración, en especial el Estado y los marcos regulatorios que elements and the sense of belonging that may be created with and within the community below:

«... the social construction of public space in popular neighborhoods in terms of interaction. In this line, the activities carried out by people allow identifying the use of such a public environment, which is transformed by those who want to satisfy their needs. In popular settlements, these activities are defined by social and cultural practices carried out in public spaces and are mostly related to socialization, communal events, traditional manifestations and religious and political expressions.»

This issue of Revista INVI features papers from three different countries: Spain, Colombia and Chile. As for the Chilean contribution, entitled «The Regulatory Framework within the Context of the Business Administration and the Commodification of Urban Development in Greater Santiago, Chile», Magdalena Vicuña del Río focuses on Santiago and discusses the issue of administration, specifically the State administration and the regulatory frameworks used to implement policy. In this case, attention is given to those regulatory frameworks related to construction urban development and derivatives. According to the author:

"...this paper is an analysis of two processes: (1) the path through which the neoliberal agenda has been applied in the regulated and operational land 
éste utiliza para llevar a la práctica sus acciones de política. En este caso, se trata de marcos regulatorios que dicen relación con la construcción y la urbanización, y los instrumentos derivados de él. La autora indica que el

...artículo constituye un análisis de dos procesos: (1) el camino a través del cual la agenda neoliberal ha sido aplicada en el urbanismo reglamentario y operacional de Santiago de Chile; y (2) la forma en que dicho camino ha mutado en la medida en que los cambios politicos y económicos del país han cristalizado en el marco regulatorio de la ciudad. Es sabido que la normativa urbana determina — junto a otros factores, como la localización y las externalidades - el valor y la rentabilidad del suelo. El marco institucional tiene un rol fundamental en la ciudad capitalista, ya que la regulación urbana (o, en su defecto, la desregulación) y el comportamiento del sector inmobiliario están estrechamente relacionados.

Las herramientas que la autora analiza han modificado sustancialmente las características del espacio y, en el caso de la ciudad de Santiago, han transformado el paisaje urbano y rural. Si bien esto último no se menciona, permite comprender la relación directa entre la dimensión política-económica y la dimensión físico-espacial del enfoque de hábitat residencial.

El enfoque de hábitat residencial permite integrar la multidimensionalidad y la multiescalaridad del proceso de construcción de lugares, para una mejor calidad de vida y sostenibilidad de los asentamientos humanos. Ello permite mirar el territorio desde development of Santiago de Chile; and (2) the way this path has evolved as the consequence of political and economic changes in the country and their effect on the regulatory framework of the city. It is widely known that urban regulation -along other factors such as localization and external developmentsdetermines the value and profitability of land. In this sense, the institutional framework plays a key role within the capitalist city given the close relationship between urban regulation (or alternatively deregulation) and the housing sector."

The instruments analyzed by the author have substantially modified the characteristics of space and, in the case of Santiago, transformed the urban and rural landscape. Though not mentioned in this contribution, the previous statement ensures the understanding of the relationship between the political-economic and physical-spatial dimensions of the residential habitat approach.

This residential habitat approach allows integrating the multidimensionality and multiscalability factors common to the place construction process, thus ensuring a better quality of life and sustainability of human settlements. Such an approximation allows analyzing the territory from a variety of perspectives (regional-neighborhood, public policies-municipal regulations, macroeconomics-microeconomics, among others.) In this line, Raquel Pérez del Hoyo and María Elia Gutiérrez Mozo, in their paper 
perspectivas de índole regional hasta vecindario, desde las políticas públicas hasta las ordenanzas locales, desde las condiciones macroeconómicas hasta las de carácter microeconómico y local, entre otras posibilidades. Es en esta línea que el artículo de Raquel Pérez del Hoyo y María Elia Gutiérrez Mozo, "Primeras políticas de vivienda en España y su influencia en la evolución de la tipología residencial: el caso de Benalúa (1883-1956)", permite comprender cómo una política pública bajo una administración débil llega a definir una expresión morfológica. Las autoras establecen que Benalúa de Alicante es

...un buen ejemplo de iniciativa privada que llegó a convertirse en referente nacional, basado en la combinación de los dos modelos descritos: empresarial y cooperativo. Fundamentando su idoneidad en el discurso recurrente de la vivienda obrera y justificándose, además, en el vacío normativo y en la carencia de un plano oficial de ensanche, Benalúa se erigió como alternativa privada, liderada por la Sociedad Anónima Los Diez Amigos (SLDA) y refrendada por 200 accionistas, a la ineficaz gestión municipal de la época, limitándose el Ayuntamiento a declarar la construcción exenta del pago del arbitrio correspondiente...

Obviamente, la evolución de una tipología residencial va imprimiendo cambios en el paisaje natural y construido, considerando que sus inicios se materializan fuera del radio urbano de la ciudad y sin una planificación previa. entitled «First Housing Policies in Spain and Their Influence on the Evolution of Residential Typology: The Case of Benalúa (1883-1956)», discuss how a public policy, coming under a weak administration, was able to define a morphological expression. The authors of this contribution state that Benalua de Alicante is:

«... a good example of a private initiative that became a national role model thanks to the combination of business and cooperative models. Basing its suitability on the working-class housing discourse as well as on the normative gap and the lack of an official expansion plan, Benalúa (led by the Society of the Ten Friends[STF]), emerged as a private alternative to the then ineffective municipal management. In this way, the role of the local Municipality was limited to declare the exemption from construction charges..."

Obviously, the evolution of a residential typology entails the modification of the natural and constructed landscape, since the origins of such a landscape took place outside the urban core and lacked any kind of planning.

Finally, this issue of Revista INVI closes with the opinion «Effects of Domestic Wood Combustion on the Indoor Quality of Air. Temuco as a Case Study" prepared by Alejandra Cortés and Ian 
Finalmente, la Revista INVI cierra con la opinión "Efectos de la combustión a leña en la calidad del aire intradomiciliario. La ciudad de Temuco como caso de estudio", de Alejandra Cortés e Ian Ridley. La pregunta que podría surgir con la presentación de este artículo y la columna vertebral que se ha tejido en torno al paisaje, es sobre tal relación y pertinencia. Sin embargo, aunque la investigación analiza,

... a través de simulaciones computacionales, la calidad del aire intradomiciliario en viviendas de Temuco, causadas por las emisiones de material particulado de una cocina a leña, ello se realiza considerando diferentes escenarios de permeabilidad y tasas de renovación de aire en un caso especifico, de modo de predecir la exposición de los ocupantes y sus riesgos de salud.

Y el paisaje es producto de la percepción de cada sujeto del medio ambiente que habita. Tal proceso, mediatizado por la contaminación interna en una vivienda producto de la calidad de la misma, posibilitará una imagen mental negativa del medio ambiente natural y construido y por tanto, del reconocimiento del paisaje de la ciudad de Temuco.

Para terminar la introducción al $N^{\circ} 78$ de Revista INVI, sirva recordar las palabras de Lewis Mumford, en su libro La Condición del Hombre:

Ritos, arte, poesía, drama, música, danza, filosofía, ciencia, mitos, religión... son todos componentes esenciales del alimento cotidiano del hombre, pues la auténtica vida de los seres humanos no sólo consiste en actividades
Ridley. The question that might arise between this paper and the axis generated around the concept of landscape precisely relates to this relationship and relevance:

«... through computer simulation, this research analyzes the indoor quality of air resulting from the particulate matter generated by a firewood kitchen. To do so, different permeability scenarios and air renewal rates are considered to predict the exposure of residents and the subsequent health risks.»

The landscape is the result of the perception of people to the environment where they live the environment they live in. This process, influenced by the internal pollution in housing (and resulting from the quality of it), is likely to create a negative mental image of the natural and developed environment and consequently, an unfavorable image of the landscape of Teтuco.

To conclude this introduction to the contents offered in this issue of Revista INVI, it is worth remembering the words of Lewis Mumford in The Condition of Man:

"... and ritual, art, poetry, drama, music, dance, philosophy, science, myth and religion are all as essential to man as his daily bread: man's true life consists not alone in the work activities that directly sustain him, but in the symbolic activities which give 
laboriosas que directamente los sustentan, sino también en las actividades simbólicas que dan sentido tanto a los procesos de su quehacer como a sus últimos productos $y$ consecuencias. ${ }^{4}$

Todos estos elementos son constitutivos del paisaje natural y construido, que bajo un enfoque de hábitat residencial, posibilita construir lugares con calidad de vida y sostenibilidad.

\section{Bibliografía/ Bibliography}

MUMFORD, LEWIS. La condición humana. En: El mito de la máquina. Técnica y evolución humana. La Rioja, España, Editorial Pepitas de Calabaza. 2010.

REAL ACADEMIA ESPAÑOLA. Diccionario de la lengua española. 22a ed. Madrid, España, Espasa Calpe. 2001.

ROMANI, VALERIO. Il paesaggio. Teoria e pianificazione. Milano, Italia, Franco Angeli Editore. 1994.

4 Mumford, 2010. significance both to the processes of work and their ultimate products and consummations."

All these elements comprise the natural and developed landscape which, from a residential habitat approach, ensures the construction of places offering quality of life and sustainability. 